\title{
Hubungan Self Control dengan Kecenderungan Narsistik Siswa Pengguna Jejaring Sosial Instagram di SMP Negeri 2 Padang
}

\author{
Nur Asiah ${ }^{1}$, Taufik $^{2}$, Firman $^{3}$ \\ ${ }^{123}$ Universitas Negeri Padang \\ *Corresponding author, e-mail: nurkons5@gmail.com
}

\begin{abstract}
Abstrak
Penelitian ini dilatar belakangi oleh maraknya siswa yang menunjukkan eksistensi diri di jejaring sosial khususnya instagram demi mengharapkan pengakuan orang lain. Salah satu faktor yang diduga mempengaruhinya adalah self control. Tujuan penelitian ini untuk: (1) mendeskripsikan kecenderungan narsistik siswa pengguna jejaring sosial instagram, (2) mendeskripsikan self control siswa pengguna jejarig sosial instagram, dan (3) menguji signifikansi hubungan self control dengan kecenderungan narsistik siswa pengguna jejaring sosial instagram. Pendekatan penelitian menggunakan pendekatan kuantitatif dengan jenis deskriptif korelasional. Subjek penelitian ini 115 siswa SMP Negeri 2 Padang. Data dianalisis dengan teknik persentase dan rumus Pearson Product Moment Correlation. Hasil penelitian ialah: (1) kecenderungan narsistik siswa pengguna jejaring sosial instagram berada pada kategori cukup tinggi, (2) self control siswa berada pada kategori tinggi, (3) dan terdapat hubungan negatif yang signifikan antara self control dengan kecenderungan narsistik siswa pengguna jejaring sosial instagram dengan koefisien korelasi -0,717 dan taraf signifikansi 0,000.
\end{abstract}

Keywords: Self Control, Narsistik, Instagram.

How to Cite: Nur Asiah, Taufik, Firman 2018. Hubungan Self Control dengan Kecenderungan Narsistik Siswa Pengguna Jejaring Sosial Instagram di SMP Negeri 2 Padang. Konselor, VV (N): pp. XX-XX, DOI: 10.24036/XXXXXXXXXX-X-XX

This is an open access article distributed under the Creative Commons 4.0 Attribution License, which permits unrestricted use, distribution, and reproduction in any medium, provided the original work is properly cited. (O2018 by author and Universitas Negeri Padang.

\section{Pendahuluan}

Remaja ialah individu yang berada pada masa peralihan dari periode anak-anak ke periode dewasa. Periode ini dianggap sebagai masa yang sangat penting dalam kehidupan seseorang khususnya dalam pembentukan kepribadian. Idealnya remaja berkembang dengan baik tidak menonjolkan perilaku yang mengarah pada perilaku negatif. Tingkah laku negatif bukan perkembangan remaja yang normal, remaja yang berkembang dengan baik akan memperlihatkan perilaku positif (Prayitno, 2006).

Pada kenyataannya, tidak semua remaja yang sedang mencari identitas diri akan melakukan usaha yang positif untuk menunjukkan eksistensi diri demi mendapatkan pengakuan diri orang lain. Salah satu cara yang dipilih remaja ialah menjadi pengguna aktif di jejaring sosial. Remaja merupakan penggemar dan pengguna paling banyak jejaring sosial instagram. Riset yang dilakukan oleh Piper Jaffary terhadap remaja Amerika Serikat menemukan bahwa 3102 (33\%) dari 9.400 orang responden remaja usia 13-19 tahun cenderung lebig menyukai instagram (Widiartanto, Kompas.com).

Untuk menumbuhkan eksistensi di sosial media instagram, remaja menggunggah foto diri (selfie) atau video yang menarik tentang dirinya pada jejaring sosial instagram disertai dengan caption atau judul yang bersifat memperkuat karakteristik foto yang diunggah. Hal tersebut dilakukan agar dapat memikat pengguna lain untuk memberikan komentar positif atau meninggalkan tanda "ike" pada foto tersebut (Suhartanti, 2016). 
Intensitas yang semakin sering dan lama menggunakan media sosial memiliki hubungan dengan narsistik (kepedulian berlebihan pada diri sendiri). Remaja akan mengalami kecenderungan untuk mengunggah foto dan video demi mendapatkan perhatian orang lain. Tindakan menarik perhatian berlebihan dilakukan remaja tersebut menunjukkan perilaku yang mengarah pada kepribadian narsistik (Durand \& Barlow, 2007).

Kepribadian narsistik merupakan gangguan kepribadian yang selalu mengkhayalkan kebesaran atau keagungan diri, kurang berempati, sangat mendambakan untuk dihormati, dan tidak sanggup melihat dari sudut pandang orang lain Remaja dengan kepribadian narsistik mengalami kesulitan untuk menerima kritik dari orang lain. Remaja yang berkepribadian narsistik mempunyai anggapan bahwa dirinya spesial, ambisisus, dan suka mencari ketenaran (Davidson, Neale \& Kring, 2010).

Faktor yang mempengaruhi narsistik adalah rendahnya kontrol diri (Vazire \& Founder dalam Harisson, 2010). Salah satu tugas perkembangan remaja adalah memperkuat self control (kemampuan mengendalikan diri). Pada kenyataannya masih banyak remaja yang belum dapat mengembangkan kontrol diri sesuai dengan tugas perkembangannya (William Kay dalam Yusuf, 2011)

Peningkatan tindakan kecenderungan narsistik siswa diasumsikan bersumber dari melemahnya kontrol diri. Remaja yang mampu mengontrol diri dengan baik, tidak akan mudah terpengaruh dengan perubahan yang terjadi dan juga dapat terhindar dari tindakan kekerasan. Thalib (dalam Firman, 2016) menjelaskan kontrol diri menggambarkan keputusan individu melakukan sesuatu melalui pertimbangan kognitif untuk menyatukan perilaku yang telah disusun untuk meningkatkan hasil dan tujuan seperti yang diinginkan.

Berdasarkan hasil dari pemberian daftar isian yang peneliti lakukan pada siswa saat Praktik Lapangan Konseling Pendidikan Sekolah (PLKP-S) di SMP Negeri 2 Padang dapat diketahui bahwa 156 dari 256 orang siswa kelas VII memiliki smartphone dan instagram dan 55 diantaranya merupakan pemakai aktif jejaring sosial instagram. Sementara itu, 162 dari 272 orang siswa kelas VIII mengaku memiliki smartphone dan instagram dan 60 diantaranya merupakan pemakai aktif jejaring sosial instagram.

Berdasarkan persentase jumlah masalah per-item dalam hasil pengolahan AUM Umum pada siswa kelas IX4 SMP Negeri 2 Padang yang peneliti administrasikan pada 1 Agustus 2017 diketahui bahwa $66,7 \%$ siswa merasa bersalah kalau HP tidak jalan atau tidak ada jaringan sehingga tidak dapat menggunakan sosial media atau sejenisnya, $62 \%$ siswa asyik menggunakan HP atau sosial media sehingga tugas pokok terabaikan, dan $57 \%$ siswa dimarahi orang tua karena terlalu banyak menggunakan HP atau sosial media. Selanjutnya berdasarkan persentase jumlah masalah per item dalam hasil pengolahan AUM Umum pada siswa kelas VIII.5 SMP Negeri 2 Padang yang peneliti administrasikan pada 1 Agustus 2017, diketahui $56,5 \%$ siswa dimarahi orang tua terlalu banyak menggunakan HP untuk sosial media, $55 \%$ siswa merasa bersalah kalau HP tidak jalan atau tidak ada jaringan sehingga tidak dapat menggunakan sosial media, dan $62,7 \%$ siswa kecanduan menikmati acara atau program tertentu melalui sosial media sehingga kehilangan waktu. Dari hasil AUM Umum yang dilakukan di dua kelas tersebut dapat di ambil kesimpulan bahwa siswa SMP Negeri 2 Padang sebagian besar kurang dapat mengontrol diri dalm penggunaan hp untuk sosial media.

Berdasarkan hasil penelitian dan fenomena yang telah diuraikan, membuktikan bahwa perilaku narsistik pada remaja cenderung meningkat. Sehingga jika dibiarkan berarti membiarkan remaja tumbuh menjadi sosok yang rapuh, egois, individualis, dan tidak memiliki kepedulian dengan lingkungan sekitar. Orang dengan kepribadian yang sehat adalah orang yang bisa mengontrol penggunaan akun yang mempunyai tanggung jawab sosial, mempunyai kreativitas dalam membagikan informasi yang sesuai dengan realitas diri dan mampu menyaring informasi yang ada di jejaring sosial. Kontrol diri yang dimiliki remaja di sekolah dilalui melalui proses pematangan dengan berbagai kegiatan yang dilakukan melalui kegiatan bimbingan dan konseling.

Remaja yang mempunyai akun instagram diharapkan dapat mengontrol dirinya agar perilaku sesuai dengan norma, serta terhindar dari perilaku impulsive 


\section{Metodologi}

Penelitian ini merupakan penelitian kuantitatif dengan dengan jenis deskriptif korelasional yang bertujuan untuk mendeskripsikan self control (X) dan kecenderungan narsistik siswa (Y). Subjek penelitian ialah siswa pengguna jejaring sosial instagram yang teridentifikasi memiliki kecenderungan narsistik yang berjumlah sebanyak 115 siswa. Instrumen yang digunakan adalah kuesioner Self Control dan kuesioner kecenderungan narsistik. Data dianalisis dengan menggunakan teknik persentase dan rumus Pearson Product Moment Correlation.

\section{Hasil Penelitian}

\section{Kecenderungan Narsistik Siswa Pengguna Instagram}

Temuan penelitian kecenderungan narsistik dapat dilihat gambarannya sebagai berikut.

Tabel 1. Kecenderungan Narsistik Siswa Pengguna Instagram

\begin{tabular}{|c|c|c|c|c|c|c|c|c|c|c|c|c|}
\hline \multirow[b]{2}{*}{ No } & \multirow[b]{2}{*}{ Aspek } & \multirow[b]{2}{*}{ Jumlah Item } & \multicolumn{4}{|c|}{ Hipotetik } & \multicolumn{5}{|c|}{ Empiris } & \multirow[b]{2}{*}{ Kategori } \\
\hline & & & 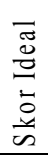 & 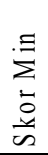 & 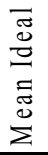 & 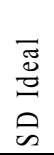 & Max & Min & Mean & $\%$ & SD & \\
\hline 1 & Perasaan Grandiose Diri Penting & 12 & 60 & 12 & 36 & 8 & 59 & 20 & 34 & 56.71 & 8 & Cukup Tinggi \\
\hline 2 & Terpreokupasi Fantasi Tanpa Batas & 4 & 20 & 4 & 12 & 2.7 & 19 & 4 & 11.6 & 58.22 & 3.4 & Cukup Tinggi \\
\hline 3 & Minta Dipuji Secara Eksesif & 4 & 20 & 4 & 12 & 2.7 & 19 & 4 & 10.6 & 52.96 & 4 & Cukup Tinggi \\
\hline 4 & Kurang Empati & 4 & 20 & 4 & 12 & 2.7 & 19 & 4 & 11.5 & 57.57 & 3 & Cukup Tinggi \\
\hline 5 & Bersikap Arogan & 5 & 25 & 5 & 15 & 3.3 & 23 & 7 & 13.8 & 27.81 & 3 & Cukup Tinggi \\
\hline & Keseluruhan & 29 & 145 & 29 & 87 & 19.3 & 132 & 48 & 81.6 & 56.27 & 19.5 & Cukup Tinggi \\
\hline
\end{tabular}

Tabel Kecenderungan Narsistik Siswa Pengguna Instagram (Nur Asiah, 2018).

Tabel 1 memperlihatkan bahwa dari keseluruhan aspek, siswa memiliki kecenderungan narsistik yang cukup tinggi yaitu sebesar $56,27 \%$. Hal ini dapat dilihat dari hasil analisis data pada masingmasing aspek, antara lain: aspek perasaan grandiose diri penting berada pada kategori cukup tinggi, yaitu sebesar $56,71 \%$, aspek terpreokupasi pada fantasi tanpa batas berada pada kategori cukup tinggi, yaitu sebesar $58,22 \%$, aspek minta dipuji secara eksesif berada pada kategori cukup tinggi, yaitu sebesar $52,96 \%$, aspek kurang empati berada pada kategori cukup tinggi, yaitu sebesar $57,57 \%$, dan aspek bersikap arogan berada pada kategori cukup tinggi, yaitu sebesar $27,81 \%$.

\section{Self Control Siswa Pengguna Instagram}

Temuan penelitian self control dapat dilihat gambarannya sebagai berikut.

Tabel 2. Self Control Siswa Pengguna Instagram

\begin{tabular}{|c|c|c|c|c|c|c|c|c|c|c|c|c|}
\hline \multirow[b]{2}{*}{ No } & \multirow[b]{2}{*}{ Aspek } & \multirow[b]{2}{*}{ Jumlah Item } & \multicolumn{4}{|c|}{ Hipotetik } & \multicolumn{5}{|c|}{ Empiris } & \multirow[b]{2}{*}{ Kategori } \\
\hline & & & 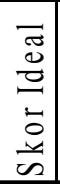 & 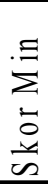 & 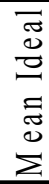 & 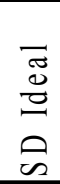 & Max & Min & Mean & $\%$ & SD & \\
\hline 1 & Mengontrol Perilaku & 11 & 55 & 11 & 33 & 7.3 & 60 & 15 & 35 & 63,72 & 7 & Sedang \\
\hline 2 & Mengontrol Kognitif & 11 & 55 & 11 & 33 & 7.3 & 53 & 16 & 38.9 & 70.77 & 8.9 & Tinggi \\
\hline 3 & Mengontrol Keputusan & 6 & 30 & 6 & 18 & 4.0 & 30 & 7 & 20.5 & 68.23 & 4 & sedang \\
\hline & Keseluruhan & 28 & 140 & 28 & 84 & 18.7 & 134 & 40 & 94.3 & 67.33 & 18.2 & Tinggi \\
\hline
\end{tabular}

Tabel Self Control Siswa dengan Kecenderungan Narsistik Siswa (Nur Asiah, 2018)

Tabel 2 memperlihatkan bahwa dari keseluruhan aspek, siswa memiliki self control yang tinggi yaitu sebesar $67,33 \%$. Hal ini dapat dilihat dari hasil analisis data pada masing-masing aspek, antara lain: aspek mengontrol keputusan berada pada kategori sedang, yaitu sebesar 63,72\%, aspek mengontrol kognitif berada pada kategori tinggi, yaitu sebesar 70,77\%, dan aspek mengontrol keputusan berada pada kategori sedang, yaitu sebesar $67,33 \%$.

\section{Hubungan Self Control dengan Kecenderungan Narsistik Siswa}

Temuan penelitian hubungan self control dengan kecenderungan narsistik siswa dapat dilihat gambarannya sebagai berikut. 
Tabel 3. Korelasi Self Control Siswa (X) dengan Kecenderungan Narsistik Siswa (Y) di SMP N 2 Padang

\begin{tabular}{|c|l|l|l|l|l|}
\hline Variabel & $\mathbf{N}$ & r-tabel & r-hitung & Sig & Ket \\
\hline $\begin{array}{c}\text { Self Control } \\
(\mathrm{X})\end{array}$ & 115 & 0,183 & $-0,717$ & 0,000 & $\begin{array}{c}\text { Berkorelasi } \\
\text { kuat }\end{array}$ \\
\cline { 1 - 3 } $\begin{array}{c}\text { Kecenderungan } \\
\text { Narsistik (Y) }\end{array}$ & & & & & \\
\hline
\end{tabular}

Tabel Hubungan Self Control dengan Kecenderungan Narsistik Siswa (Nur Asiah, 2018)

Hasil yang diperoleh mengungkapkan bahwa terdapat hubungan negatif yang positif signifikan antara self control dengan kecenderungan narsistik siswa pengguna jejaring sosial instagram di SMP Negeri 2 Padang.

\section{Pembahasan}

\section{Kecenderungan Narsistik Siswa Pengguna Instagram}

Berdasarkan hasil penelitian mengenai kecenderungan narsistik siswa pengguna jejaring sosial instagram di SMP Negeri 2 Padang siswa memiliki kecenderungan narsistik yang cukup tinggi yaitu sebesar $56,27 \%$. Berdasarkan hal tersebut dapat dijelaskan bahwa remaja menggunakan jejaring sosial instagram untuk menunjukkan keberadaan dirinya kepada orang lain (Hurlock, 1980: 208). Perilaku yang ditunjukkan siswa tersebut mengarah pada kepribadian narsistik.. Berikut uraian dari hasil analisa masing-masing karakteristik narsistik.

\section{a. Perasaan Grandiose bahwa Dirinya Orang Penting}

Berdasarkan hasil analisis data yang dilakukan menunjukkan bahwa karakteristik narsistik berupa perasaan grandiose bahwa diri penting pada siswa SMP Negeri 2 Padang berada pada kategori cukup tinggi, dengan persentase skor rata-rata 56,71\%. Artinya sebagian besar siswa SMP Negeri 2 Padang merasa dirinya penting yang berlebihan.

Grandiosity dan self important merupakan ciri khas utama yang ditampilkan dalam narsistik. Kombinasi keduanya merupakan akibat untuk bersikap mementingkan diri sendiri dan perilaku defensive yang ditampilkan pada perilaku narsisme (Myers dan Hill, 2011). Remaja menampakkan adanya perasaan luar biasa bahwa dirinya sebagai individu yang penting dan berlebihan agar orang lain mengetahuinya.

b. Terpreokupasi dengan Fantasi-fantasi tanpa Batas.

Berdasarkan hasil analisis data yang dilakukan menunjukkan bahwa karakteristik narsistik berupa terpreokupasi dengan fantasi tanpa batas, siswa SMP Negeri 2 Padang berada pada kategori cukup dengan persentase 58,22\%. Artinya sebagian besar siswa SMP Negeri 2 Padang mempunyai khayalan dengan kesuksesan, kecerdasan, dan kecantikan. Kernberg (dalam Suhartanti, 2016) menyatakan induividu dengan kecenderungan narsistik memiliki fantasi berlebih dalam hal kecerdasan, kecantikan dan kekuatan yang ia miliki. Dengan demikian siswa perlu diberi arahan serta pemahaman untuk dapat membatasi khayalan dan harapan yang tidak masuk akal.

c. Minta Dipuji secara Eksesif

Berdasarkan hasil analisis data yang dilakukan menunjukkan bahwa karakteristik narsistik berupa minta dipuji secara eksesif, siswa SMP Negeri 2 Padang berada pada kategori cukup tinggi dengan persentase $52,96 \%$. Kecenderungan untuk meminta pengaguman serta pujian dari orang lain merupakan bentuk kurangnya penerimaan diri sehingga timbul keinginan untuk memperbaiki kekurangan yang ada pada dirinya (Widiyanti, 2017). Perlu perhatian khusus pada siswa yang termasuk kedalam kategori tinggi pada aspek ini.

d. Kurang Empati

Berdasarkan hasil analisis data yang dilakukan menunjukkan bahwa karakteristik narsistik berupa kurang empati, siswa SMP Negeri 2 Padang berada pada kategori cukup dengan persentase $57,7 \%$. Keterpusatan terhadap diri menajdikan individu tidak menghiraukan dunia selain dirinya sendiri dan tidak memiliki empati (Widiyanti, 2017). Artinya, siswa yang kurang pengertian atau perhatian terhadap orang lain disebabkan oleh adanya anggapan bahwa diri mereka lebih tinggi dibandingkan orang lain. Kepercayaan tersebut kemudian menghambat kemampuan mereka untuk merasakan kepekaan terhadap lingkungan.

\section{e. Bersikap Arogan}

Berdasarkan hasil analisis data yang dilakukan menunjukkan bahwa karakteristik narsistik berupa bersikap arogan, siswa SMP Negeri 2 Padang berada pada kategori cukup 
dengan persentase $55,27 \%$. Artinya sebagian besar siswa SMP Negeri 2 Padang memiliki sikap arogan terhadap orang lain. Sependapat dengan itu, Maria (dalam Swastika, 2017) menyatakan bahwa orang yang narsistik akan menunjukkan sifat sombong, angkuh dan merendahkan oang lain. Ini artinya perlu perhatian khusus untuk siswa agar tidak timbul sikap arogan dan merendahkan orang lain.

\section{Self Control Siswa Pengguna Instagram}

Berdasarkan hasil penelitian mengenai self control siswa secara keseluruhan dapat diketahui bahwa sebagian besar self control siswa di SMP Negeri 2 Padang berada pada kategori tinggi dengan persentase 67,33\%. Hal ini menandakan bahwa sebagian besar siswa di SMP Negeri 2 Padang sudah mampu mengontrol dirinya. Menurut Ghufron dan Risnawita (2010:21), self control pada diri seseorang akan terlihat ketika ia mampu membimbing, mengatur, dan mengarahkan perilakunya ke arah yang lebih baik.

Banyak faktor yang mempengaruhi tinggi rendahnya self control seseorang, faktor dari dalam diri seperti usia dan faktor dari luar diri seperti lingkungan keluarga. Kemampuan mengontrol diri berkembang seiring dengan bertambahnya usia kemudian lingkungan keluarga terutama orang tua menentukan bagaimana kemampuan self control seseorang (Ghufron dan Risnawita, 2010).

Ada tiga usaha untuk memaksimalkan self control, yaitu: pertama, membuat atau memodifikasi lingkungan menjadi responsif atau menunjang tujuan-tujuan yang ingin dicapai individu. Kedua memperbanyak informasi dan kemampuan untuk menghadapi atau menyesuaikan diri dengan lingkungan. Ketiga, menggunakan secara efektif kebebasan memilih dalam pengaturan lingkungan. berikut:

Selanjutnya pembahasan hasil penelitian berdasarkan aspek masing-masing yaitu sebagai

\section{a. Mengontrol Perilaku}

Berdasarkan hasil pengolahan data dapat diketahui bahwa self control siswa di SMP Negeri 2 Padang untuk aspek mengontrol perilaku berada pada kategori sedang dengan persentase $63,72 \%$. Dalam mengontrol perilaku ini terdapat dua komponen yaitu kemampuan mengatur pelaksanaan dan kemampuan mengontrol stimulus. Menurut Thalib (2010:107), seseorang akan melakukan tindakan yang efektif untuk menghasilkan sesuatu yang diinginkan.

Ada beberapa cara yang dapat digunakan dalam mengontrol perilaku, yaitu mencegah atau menjauhi stimulus, menempatkan tenggang waktu di antara rangkaian timulus yang sedang berlangsung, menghentikan stimulus sebelum waktunya berakhir dan membatasi intensitasnya (Ghufron dan Risnawita, 2010).

\section{b. Mengontrol Kognitif}

Berdasarkan pengolahan data dapat disimpulkan bahwa self control siswa di SMP Negeri 2 Padang untuk aspek mengontrol kognitif berada pada kategori tinggi dengan persentase $70,77 \%$. Hal ini menandakan bahwa rata-rata siswa sudah mampu mengontrol kognitifnya. Menurut Piaget (dalam Ghufron dan Risnawita, 2010) remaja telah mencapai tahap pelaksanaan formal dalam kemampuan kognitif..

Siswa dapat mengontrol kognitifnya dengan memperbanyak informasi yang diperoleh seseorang, sehingga informasi yang diperoleh tersebut dapat mengembangkan kemampuan kognitifnya.

\section{c. Mengontrol Keputusan}

Berdasarkan hasil penelitian dapat disimpulkan bawah self control siswa di SMP Negeri 2 Padang untuk aspek mengontrol keputusan berada pada kategori sedang dengan persentase $68,23 \%$. Hal ini menjelaskan bahwa sebagian besar siswa sudah mampu mengontrol keputusannya.

Averill (dalam Ghufron dan Risnawita, 2010), menyatakan bahwa kontrol diri dalam mengontrol keputusan dapat maksima dengan adanya suatu kesempatan, kebebasan, atau kemungkinan pada diri individu untuk memilih berbagai kemungkinan tindakan. Guru dapat memberikan kesempatan, kebebasan kepada siswa untuk memilih berbagai tindakan belajarnya. Hal ini merupakan salah satu usaha agar kemampuan mengontrol keputusan dapat berkembang dengan baik.

Kontrol diri individu berkaitan dengan kematangan emosi masing-masing individu. Hurlock (dalam Firman, 2016) menjelaskan kriteria kontrol diri dalam aspek emosi yang matang, yaitu : (1) dapat melakukan kontrol diri yang bisa diterima oleh masyarakat social, (2) dapat memahami seberapa banyak kontrol yang dibutuhkan untuk memuaskan kebutuhannya dan sesuai 
dengan harapan masyarakat dan (3) dapat menilai situasi secara kritis sebelum merespon dan memutuskan cara bereaksi terhadap situasi berikutnya.

\section{Hubungan Self Control dengan Kecenderungan Narsistik Siswa Pengguna Jejaring Sosial Instagram}

Selanjutnya penelitian ini dilakukan untuk mengetahui ada tidaknya hubungan antara self control dengan kecenderungan narsistik siswa pengguna jejaring sosial instagram di SMP Negeri 2 Padang. Hasil yang diperoleh mengungkapkan bahwa terdapat hubungan negatif yang positif signifikan antara self control dengan kecenderungan narsistik siswa pengguna jejaring sosial instagram di SMP Negeri 2 Padang.Hubungan yang signifikan negatif ini dapat diartikan, semakin tinggi self control maka kecenderungan narsistik siswa semakin rendah. Sebaliknya, semakin rendah self control maka kecenderungan narsistik siswa semakin tinggi.

Berdasarkan pengujian korelasional terdapat hubungan yang negatif antara self control dengan kecenderungan narsistik. Maka ada peluang untuk menurunkan atau mencegah narsistik ini dengan meningkat kan self control. Marita (dalam Swastika, 2017) menyatakan ada beberapa cara untuk meningkatkan self control, diantaranya: (a) mengendalikan diri dengan prinsep kemoralan, seperti menjaga sikap, ucapan dan pikiran. (b) menggunakan kesadaran ketika pikiran atau perasaan negatif muncul. (c) melakukan perenungan. (d) menyibukkan diri dengan pikiran atau aktivitas positif.

\section{Kesimpulan dan Saran}

Berdasarkan hasil analisis data yang telah dibahas, maka dapat disimpulkan bahwa:

1. Kecenderungan narsistik siswa pengguna jejaring sosial instagram secara umum berada pada kategori cukup tinggi.

2. Self control secara umum berada pada kategori tinggi.

3. Terdapat hubungan negatif yang signifikan antara self control dengan kecenderungan narsistik siswa pengguna jejaring sosial instagram,. Artinya, mahasiswa yang memiliki tingkat self control rendah maka kecenderungan narsistik siswa tinggi, begitu pula sebaliknya jika self control tinggi maka kecenderungan narsistik siswa rendah.

Berdasarkan hasil penelitian, maka peneliti mengemukakan saran sebagai berikut.

1. Bagi siswa yang memiliki kecenderungan narsistik, diharapkan untuk meningkatkan self control-nya antara lain dalam mengontrol perilaku, kognitf, dan keputusan.

2. Bagi guru BK, dapat memberikan layanan penguasaan konten dan bimbingan kelompok tentang usaha untuk meningkatkan self control siswa, sehingga siswa mendapatkan keterampilan dalam mengontrol dirinya.

3. Bagi pihak sekolah, untuk meningkatkan fasilitas bagi guru BK dan siswa untuk melaksanakan layanan bimbingan kelompok, konseling kelompok, layanan penguasaan konten dan konseling individual yang diduga berguna bagi siswa untuk meningkatkan self control.

4. Bagi peneliti selanjutnya diharapkan dapat melanjutnya penelitian ini penelitian ini bermanfaat sebagai usaha meningkatkan keterampilan, menambah wawasan dan pengetahuan dalam melakukan penelitian serta mampu memberikan kontribusi positif bagi penelitian selanjutnya. Diharapkan untuk mempertimbangkan faktor lain yang ikut mempengaruhi kecenderungan narsistik siswa.

\section{Daftar Rujukan}

Agosto, D., E. \& Abbas, J. (2009). Teens and Social Networking: How Public Libraries are Responding to The Latest Online Trend. Public Libraries, Vol 48, 32-37.

Davison, G. C., Neale, J. M., Kring, \& Kring, A. M. (2006). Psikologi Abnormal Edisi Kesembilan. Alih Bahasa: Noermalasari Fajar. Jakarta : Rajawali Press.

Durand, V. M. \& Barlow, D. H. (2007). Psikologi Abnormal. Yogyakarta: Pustaka Pelajar.

Ghufron, M. N \& Risnawita, S. R. (2014). Teori-Teori Psikologi. Jakarta: Ar-Ruzz Media.

Firman, Karneli, Y., Hariko, R. (2016). Pencegahan Tindakan Kekerasan Melalui Pengembangan Panduan Pelaksanaan Layanan Informasi Menggunakan Pendekatan Problem Solving Dalam Peningkatan Kontrol Diri Siswa Sekolah Menengah Kejuruan (Smk) Kota Padang. Padang: FIP UNP

Handayani, N. (2014). Hubungan antara Kontrol Diri dengan Narsisme Pada Remaja Pengguna Facebook. Skripsi. Tidak diterbitkan. Surakarta: Fakultas Psikologi UMS. 
Hurlock, E. B. (1980). Psikologi Perkembangan Suatu Pendekatan Sepanjang Rentang Kehidupan. Edisi kelima. Alih Bahasa: Istiwidayanti \& Soedjarwo. Jakarta: Erlangga.

Muna, R. F. \& Astuti, T. P. (2014). Hubungan antara Kontrol Diri dengan Kecenderungan Kecanduan Media Sosial pada Remaja Akhir. Jurnal Fakultas Psikologi 3(4). 7-8.

Nevid, J. S., Rathus, S. A., \& Greene, B. (2003). Psikologi Abnormal. Edisi kelima Jilid 1. Jakarta: Erlangga.

Prayitno, E. (2006). Bahan Ajar Psikologi Perkembangan Remaja. Padang: Angkasa Raya.

Santrock, J. W. (2003). Adolence: Perkembangan Remaja (Edisi ke -6). Alih bahasa Shinto B. Adelar; Sherly Saragih). Jakarta: Erlangga.

Santi, N. N. (2017). Dampak Kecenderungan Narsiscisme Terhadap Self Esteem pada Pengguna Facebook Mahasiswa PGSD Universitas Nusantara PGRI. Jurnal Dimensi Pendidikan dan Pembelajaran Vol. 5 No.1, 29.

Swastika, A.A. (2017). Hubungan Kontrol Diri dengan Perilaku Narsistik Remaja Putri Presenter Bigo Live di Surabaya. Skripsi. Tidak diterbitkan. Surabaya: Universitas 17 Agutus 1945 Surabaya.

Suhartanti, L (2016). Pengaruh Kontrol Diri Terhadap Narciccictic Personality Disorder pada Pengguna Sosial Instagram Di SMA N 1 Seyegan. Skripsi. Yogyakarta: UNY

Tamimy, M. F. (2017). Sharing-mu, Personal Branding-mu: Menampilkan Image Diri dan Karakter di Media Sosial. Bandung: VisiMedia.

Thalib, S. B (2010). Psikologi Pendidikan Berbasis Analisis Empiris Aplikatif, Jakarta: Kencana.

Widiartanto, Y. H. (2015). Remaja Pilih Mana, Facebook atau Instagram. Diaksesdarihttp://tekno.kompas.com/read/2015/10/21/15440037/Remaja.Pilih.Mana.Faceboo k.atau.Instagram. Diakses tanggal 9/01/2018 jam 15.21 WIB.

Wulandari, R. (2015). Hubungan Antara Kontrol Diri Dengan Kecanduan Game Online Pada Remaja Di Warnet Lorong Cempak Dalam Kelurahan 26 Ilir Palembang. Jurnal Fakultas Psikologi. Universitas Bina Darma Palembang. 133, 123-145

Yusuf, S. (2001). Psikologi Perkembang Anak \& Remaja. Bandung: Remaja Rosdakarya 